

Patryk Suchodolski*

Książnica Podlaska im. Łukasza Górnickiego w Białymstoku, Polska

ORCID: 0000-0002-2401-4576

\title{
Postęp a konserwatyzm. „Kwestia włościańska” w ujęciu Zygmunta Glogera i Gustawa Manteuffla
}

Progress vs. Conservatism. "Peasants' Issue" in the Views of Zygmunt Gloger and Gustaw Manteuffel

Abstract: In the article the author muses upon differences between concepts of progressiveness and conservatism, about how $19^{\text {th }}$ century publicists understood them. Narrowing the field of considerations, he focuses on so called "peasants' issue", social changes in the province after the abolition of serfdom, attitudes towards them as the representatives of classes commonly seen as conservative, aristocratic and land gentry. The confrontation of their views with the ideas shared by positivists, in this case of Stefania Ulanowska, Aleksander Świętochowski and Julian Ochorowicz, leads to the conclusion that classification into progressive or conservative is problematic and artificial, which was already observed in second half of the $19^{\text {th }}$ century.

Keywords: Gloger, Manteuffel, Ulanowska, Świętochowski, Polish literary, $19^{\text {th }}$ century.

\footnotetext{
Patryk Suchodolski - mgr, pracownik naukowy Książnicy Podlaskiej im. Łukasza Górnickiego w Białymstoku. Autor szeregu artykułów, w tym: Grodzieńszczyzna w badaniach Zygmunta Glogera (2018).
} 
Patryk Suchodolski, Postęp a konserwatyzm...

Konserwatyzm i postęp często są postrzegane jako wrogie żywioły, których nieuchronna konfrontacja zawsze prowadzi do zawsze tych samych rezultatów ${ }^{1}$. Nowe koncepcje, idee, wartości tryumfują nad starymi tylko po to, by z czasem stać się anachronizmami toczącymi ze swoimi następcami walkę, której nie mogą wygrać. We Wstępie i poglądzie ogólnym na filozofię pozytyw$n q$ Julian Ochorowicz pisał:

[...] jeden pogląd niejako wysnuwa się z drugiego i dopiero, gdy jeden z nich rozwinie się do pewnego najwyższego kresu, na jaki mu ogólny stan oświaty w danej epoce pozwala, wówczas, przygotowany już przez historię, również mocą ciągłości, wprost przeciwny mu prąd idei występuje do walki².

Dialektyka tak rozumianego procesu dziejowego sprawia wrażenie zgodnej z padającymi w głośnym manifeście My $i$ wy słowami Aleksandra Świętochowskiego o ,popalonych mostach” i ,pozrywanych groblach” pomiędzy obozami „starej” oraz „młodej” prasy33. Ci czołowi przedstawiciele warszawskiego pozytywizmu zdają się nie dostrzegać żadnych płaszczyzn porozumienia z pokoleniem romantyków. W ich optyce przeciwstawne wektory „prądów idei” skazują je na nieuchronną kolizję, walkę nie tylko o własną przyszłość, ale również przyszłość społeczności, na gruncie których wyrosły. Jednak czy stanowiska obu ugrupowań rzeczywiście nie były możliwe do pogodzenia w żadnym aspekcie, a wszystkie ich postulaty antynomiczne? Czy było tak w przypadku tzw. kwestii włościańskiej, czyli uwłaszczenia chłopów? W Królestwie Polskim próbowały je przeprowadzić władze powstania styczniowego, dokonały się na mocy ukazu carskiego z 1864 roku. Podobnej reformy dokonano w Imperium Rosyjskim w roku 1861, co przyniosło prowincji ogromne

1 Publikacja finansowana w ramach programu Ministra Nauki i Szkolnictwa Wyższego pod nazwą „Narodowy Program Rozwoju Humanistyki” w latach 2018-2022. Tytuł projektu: Kontynuacja naukowej, krytycznej edycji „Pism rozproszonych” Zygmunta Glogera: edycja rękopisów, pism etnograficznych, rysunków i korespondencji w siedmiu tomach.

2 J. Ochorowicz, Wstęp i pogląd ogólny na filozofię pozytywna, Warszawa 1872, s. 7.

3 [A. Świętochowski], My $i$ wy, „Przegląd Tygodniowy” 1871, nr 44, s. 357. 
zmiany. Jaki stosunek mieli do nich przedstawiciele warstw powszechnie uważanych za zachowawcze? Czy był skrajnie odmienny od stanowisk pozytywistycznych, jak wynikałoby z wypowiedzi Świętochowskiego i Ochorowicza? Co o „kwestii włościańskiej” myśleli inflancki arystokrata baron Gustaw von Manteuffel i podlaski ziemianin Zygmunt Gloger, postać trudna do zaklasyfikowania, do której przylgnęły takie określenia, jak „liberalny konserwatysta”4, „romantyczny pozytywista”, który „kochał lud”, ale „bał się jego samodzielności”?6

\section{Egipcjanin}

Egipcjaninem nazwała Gustawa von Manteuffla dzieląca z nim fascynację Inflantami Stefania Ulanowska, autorka pracy Łotysze Inflant polskich, a w szczególności gminy wielońskiej powiatu rzeżyckiego. W 1894 roku na łamach „Kwartalnika Historycznego” pisała:

Temu panu [Manteufflowi - P. S.] i jemu podobnym chciałoby się, aby ludek po staremu był uległy pewnym starym, tradycyjnym powagom i aby był pokornym podścieliskiem pewnych kast uprzywilejowanych. Każdy głos mówiący, że albo tak już nie jest, albo tak być nie powinno wywołuje u Egipcjan naszych lamenty, a za lamentami idzie poniżanie i czernienie tych, którzy credunt aliter?

Mimo miażdżącej krytyki, do Manteuffla przylgnęło określenie „,przyjaciela Łotyszy”. Czemu taka inskrypcja, zapisana w języku łatgalskim, a więc włościan dawnych Inflant polskich, znajduje się na jego nagrobku w łotewskich Drycanach? Arystokrata zasłynął jako badacz i znawcza inflanckiej historii, folkloru, ludności. Czy to wystarczyło, by zasłużyć na takie upamiętnienie? Ulanowska otwarcie zarzucała mu wstecznictwo, chęć utrzymania przeduw-

4 J. Lawski, Zygmunt Gloger i wiek XIX, [w:] Z. Gloger, Pisma rozproszone, t. I, red. J. Leończuk, J. Ławski, Białystok 2014, s. 27.

5 T. Komorowska, Romantyczny pozytywista, [w:] tejże, Zygmunt Gloger. Opowieść biograficzna, Warszawa 1985.

6 H. Syska, Zygmunt Gloger, Warszawa 1963, s. 135.

7 Zob. S. Ulanowska, [Od. p. Stefanii Ulanowskiej z Moskwy otrzymujemy nastepujące pismo], „Kwartalnik Historyczny” 1894, R. VIII, s. 582. 
łaszczeniowej, wertykalnej relacji ziemian oraz chłopów, którą przyrównała do niewolnictwa. Jak zwolennik feudalnego porządku społecznego mógł zasłużyć na tytuł przyjaciela włościan? Zwłaszcza, że opinia autorki Łotyszy Inflant polskich zdaje się być racjonalna. Przedstawiła ona Manteuffla jako typowego, a przynajmniej stereotypowego, przedstawiciela arystokracji, zepsutej, gnuśnej grupy społecznej w drugiej połowie XIX stulecia systematycznie tracącej na znaczeniu, którą mierziło uniezależnienie się dotychczas utrzymujących ją poddanych. Na pierwszy rzut oka może wydawać się, że baron istotnie uosabiał archetypiczne wady warstw wyższych - arogancję, samouwielbienie, narcyzm, apodyktyczność ${ }^{8}$. Jednak uznanie tej oceny za trafną nie rozstrzyga problemu genezy drycańskiej inskrypcji.

W pismach rzekomego „Egipcjanina” próżno doszukać się tęsknoty za „starymi, dobrymi czasami”. Wręcz przeciwnie, ich lektura ujawnia pozytywną ocenę przemian cywilizacyjnych, które nastąpiły w rezultacie uwłaszczenia w roku 1861. Manteuffel z aprobatą pisał o ograniczeniu pijaństwa, szerzeniu oświaty wśród ludności prowincjonalnej Inflant polskich, jej stopniowym bogaceniu. Przy tym wypowiadał się krytycznie o dawnych zależnościach feudalnych, które według niego „do przyttumienia rozumu i lenistwa wiele się przyczyniały”.

Mimo to, nie było mu po drodze z inflanckimi postępowcami. Uważał ich za oderwanych od wiejskiej rzeczywistości. W jego opinii realizowali nie społecznie pożądany program podniesienia poziomu intelektualnego, moralnego,

8 Świadectwo o charakterze barona daje prowadzona przez niego polemika ze Stefanią Ulanowską (oprócz wspominanego w powyższym przypisie artykułu zob. również „Kwartalnik Historyczny" 1892, R. VI i 1895, R. IX oraz A. Rataj, Stefania Ulanowska. Tajemniczy życiorys, niepublikowane fragmenty twórczości, Białystok 2016; T. Rączka, Kilka stów o Stefanii Ulanowskiej i jej spuściźnie, na marginesie reprintu „Łotyszy Inflant polskich”, „Zapiski historyczne poświęcone historii Pomorza i krajów bałtyckich" 2013, t. LXXVIII, z. 4. ) oraz jego korespondencja z Tadeuszem Korzonem dotycząca recenzji Zarysu z dziejów krain dawnych inflanckich, w której o krytykach jego pracy wypowiadał się następująco: ,[...] że autorowi tych skromnych Zarysów niepodobna uwzględnić ani jednej z uwag obu referentów [...] gdyż ma on przekonanie niezłomne, iż ze względu na lekkomyślność sądów wygłaszanych nieraz z całą bezwzględnością pseudokompetencji, nauka historii, która bardziej od innych gałęzi wiedzy ulega nieopatrznym sądom [...] musi ustrzegać się błędności źródeł i wiadomości, najczęściej tendencyjne szerzonych. [...] Lubo radbym prostować wszystko co być może krzywym w tej skromnej pracy [...], w żadnym jednak razie nie mogę [...] zgodzić się, aby w niej krzywiono co proste" (cyt. za: J. Bardach, O niepublikowanych „Zarysach dziejów Inflant” Gustawa Manteuffla, „Przegląd Zachodni” 1986, nr 5-6, s. 25-26).

9 G. Manteuffel, Inflanty polskie poprzedzone ogólnym rzutem oka na siedmiowiekowa przeszłość całych Inflant, [w:] tegoż, Inflanty polskie oraz listy znad Battyku, wstęp, red. i oprac. K. Zajas, Kraków 2009, s. 58-60. 
ekonomicznego ludności włościańskiej, a własne aspiracje kreacji łotewskiej literatury narodowej. O wydawanych przez nich publikacjach pisał: „Przekłady artykułów z pism ludowych, którymi najczęściej gardzą [redaktorzy pism łotewskich - P. S.], przyniosłyby niewątpliwie korzyść prawdziwą, [...] wtenczas, kiedy większa część dzieł, obecnie przekładanych [...], w żadnym razie tego szlachetnego celu osiągnąć nie zdoła"10. Suchej nitki nie zostawił na lwiej części wydawnictw prasowych, uważając uprawianą w nich publicystykę za „agitatorską, pseudopostepową"11.

Tak sformułowany zarzut swoistego absenteizmu inflanckich postępowców, wręcz wstecznictwa ${ }^{12}$, podawał w wątpliwość zdolność inteligencji do przewodzenia ludowi na jego drodze ku faktycznej, a nie tylko formalnej emancypacji. Wobec indolencji miejskich intelektualistów Manteuffel zadanie to powierzał ziemiaństwu oraz Kościołowi katolickiemu, a więc bliskim mu kręgom, powszechnie uważanym za konserwatywne. Uważał, że w odróżnieniu od samozwańczych modernizatorów posiadają one dogłębną wiedzę o prowincjonalnej rzeczywistości, a zarazem dysponują odpowiednim potencjałem ekonomicznym oraz intelektualnym ${ }^{13}$. Wydaje się, że takie stanowisko musiało stać w sprzeczności z dążeniami pozytywistycznymi. Tymczasem Aleksander Świętochowski w Pracy u podstaw pisał o roli ziemiaństwa w zadaniu podźwignięcia wsi Królestwa Polskiego tak:

W sprawie tej cały ciężar obowiązków złożonym być musi na element oświeceńszy, to jest na obywateli ziemskich. Zadanie ich przedstawia się w takim kształcie: dla dobra ogółu, kmieci i własnego winni oni środkami ustawą niewzbronionymi zdobyć wpływ na sprawy ludu i jego życiowy rozwój, nawiązać pomiędzy nim a sobą pasmo ścisłych spójni. Naturalnie mówimy tu przede wszystkim o wpływach moralnych, a nie zwierzchniczych ${ }^{14}$.

10 G. Manteuffel, Łotwa i jej pieśni gminne, [w:] tamże, s. 235.

11 Tamże, s. 237.

12 Zob. podtytuł I części Łotwy i jej pieśni gminnych, z której pochodziły fragmenty dotyczące stosunku Manteuffla do inteligencji Inflant - [...] Stosunki socjalno-polityczne; kierunek wsteczny wielkiej części prasy totewskiej, [w:] G. Manteuffel, Portrety miast inflanckich. Pieśni gminne, wstęp i red. K. Zajas, oprac. K. Łopatecki i W. Walczak, Białystok 2013, s. 221.

13 Tenże, Inflanty polskie..., s. 59-60.

14 [A. Świętochowski], Praca u podstaw, cz. I, ,Przegląd Tygodniowy” 1873, nr 10, s. 74. 
Redaktor „Przeglądu Tygodniowego” podobną rolę wyznaczył wiejskiemu klerowi, zdając sobie sprawę z jego niebagatelnego wpływu na ludność chłopską. W jego opinii pleban, często postrzegany przez włościan jako wyrocznia tak w sprawach sacrum, jak profanum, miał zadatki, by stać się ich prawdziwym opiekunem i przewodnikiem. Choć musiał się do tego odpowiednio przygotować, zrozumieć istotę zadania oraz znaczenie własnej posługi:

I dlatego jeżeli duchowieństwo chce „zużytecznić się" dla kraju, powinno: 1) ciągle uzupełniać własne wykształcenie, 2) zajmować się oświatą, 3) za pośrednictwem ambony i konfesjonału wywierać wpływ zdrowy, z świeckimi intencjami człowieka zgodny, a postępom cywilizacji odpowiedni ${ }^{15}$.

Przytoczone argumenty podważają narrację Ulanowskiej o Manteufflu-„Egipcjaninie”. Baron dobrze rozumiał potrzeby prowincji i pochwalał kierunek zachodzących zmian. Przyznając ziemiaństwu oraz duchowieństwu główną rolę w dziele reformy stosunków społecznych pouwłaszczeniowej wsi, również nie występował przeciwko programowi pozytywistycznemu - przynajmniej w wersji nakreślonej przez Świętochowskiego w Pracy u podstaw. Zatem z czego wynikły tak mocne słowa autorki Łotyszy Inflant polskich...? Zdaje się, że jej opinia była tyleż niesprawiedliwa, co, przynajmniej w znacznym stopniu, podyktowana osobistymi animozjami. By zrozumieć podłoże konfliktu obojga badaczy, warto nieco lepiej poznać opinię Manteuffla o ludzie inflanckim:

Są oni po większej części leniwi, obojętni na wszystko, oprócz własnego interesu [...]. [...] wstręt do pracy i ociężałość umysłu charakterystycznie Łotyszów cechują. W stosunku do możniejszych są uniżeni, pokorni, ale kiedy czują się silniejszymi, zaraz stają się uparci, fałszywi i podstępni ${ }^{16}$.

Mimo to, baron uważał, że „polsko-inflancki Łotysz z natury nie jest ani zły, ani głupi, do wszystkiego okazuje wrodzone zdolności, łatwo przyjmuje

15 Tamże, cz. V, „Przegląd Tygodniowy” 1873, nr 16, s. 122.

16 G. Manteuffel, Inflanty polskie..., s. 58. 
oświatę, umie pomóc sobie w trudniejszych okolicznościach. Posiada wiele talentu i zręczności"'17. Zalety te w jego oczach dopełniała poczciwość włościan, którzy byli „W przecięciu charakteru łagodnego, cichego, lubią przede wszystkim życie spokojne, są uczciwi, nabożni, dosyć pracowici, cierpliwi i roztropni, a w ogóle nie odznaczają się chciwością"18.

$\mathrm{Z}$ tą przychylną, choć niebezkrytyczną opinią nie zgadzała się Stefania Ulanowska. Autorka Łotyszy Inflant polskich bohaterów swej pracy oceniała stosunkowo nisko, zwłaszcza pod względem poziomu moralnego ${ }^{19}$. Manteuffel bardzo stanowczo wystąpił w ich obronie, publikację badaczki nazywając „zgryźliwą wycieczką”, zaś jej tezy wymysłami, którym „każdy rodowity Inflantczyk, znający prawdziwie lud tutejszy, bezwarunkowo zaprzeczyć musi”20. Obraz łotewskiej wsi kreślony przez Ulanowską uważał za nierealnie mroczny, zaś jej ludność, w jego opinii, za przedstawioną w skrajnie złym świetle, sugerującym, że jest „niezwykłą nieobyczajnością skażona"21:

A Jeśliby z tych piosenek, przez panią Ulanowską sklecanych i przytaczanych [...] i z opisów obyczajów łotewskich [...] ktoś chciał powziąć wyobrażenie o polskoinflanckich Łotyszach - musiałby ich już chyba wziąć za kanibalów [...]. Lud ten bowiem jest religijnym, wiernym i usłużnym. Nie jest tak złym, ani tak głupim i zabobonnym, jak to usiłuje przedstawić szanowna autorka [...] $]^{22}$.

Powyższe cytaty pochodzą z recenzji Łotyszy Inflant polskich autorstwa Manteuffla, opublikowanej na łamach „Kwartalnika Historycznego” w 1892

17 Tamże, s. 62. Podobną opinię powtórzył w 1882 roku: zob. Inflanty, [w:] Słownik geograficzny Królestwa Polskiego i innych krajów stowiańskich, t. III, red. F. Sulimierski, B. Chlebowski, W. Walewski, Warszawa 1882, s. 283.

18 Tenże, Listy znad Battyku, [w:] tegoż, Inflanty polskie..., s. 212-213.

19 S. Ulanowska, Łotysze Inflant polskich, a w szczególności z gminy Wielońskiej powiatu Rzeżyckiego. Obraz etnograficzny, „Zbiór Wiadomości do Antropologii Krajowej” 1891, t. XV, s. 204-206.

20 G. Manteuffel, Ulanowska Stefania: Lotysze Inflant polskich, a w szczególności z gminy Wielońskiej powiatu Rzeżyckiego, obraz etnograficzny, „Kwartalnik Historyczny” 1892, R. VI, s. 599.

21 Tamże, s. 591.

22 Tamże, s. 600. 
roku. Ulanowska odpowiedziała na zarzuty barona, jednak oprócz treści merytorycznych jej replika zawierała kilka uszczypliwości. Wiele wskazuje na to, że za jedną z nich należy uznać wypowiedź badaczki, w której zaliczyła adwersarza do „Egipcjan”.

\section{Podlaska perspektywa}

Roztaczana przez Manteuffla wizja stosunków społecznych na inflanckiej wsi wprawdzie nie jest idylliczna, ale wyidealizowana. Baron nie wspominał o problemach, które przyniósł ze sobą rok 1861 . W jego optyce stosunki prowincjonalne nie były wzorowe, jednak rozwijały się pomyślnie, zaś zachodzące wówczas przemiany pozwalały wierzyć w świetlaną przyszłość. Zgoła inaczej wydawał się na nie zapatrywać Zygmunt Gloger. Pomimo postępu cywilizacyjnego, który dokonał się na partykularzu, dostrzegał on liczne problemy wynikające ze zmiany stosunków społecznych. W jego opinii uwłaszczenie przyniosło zwiększenie skali przestępczości, w tym kradzieży i zabójstw, rozdrobnienie własności ziemskiej, przyczyniające się do postępującego ubożenia gospodarstw, upadek moralny wynikający ze stopniowego odwracania się od tradycyjnych wartości. Dopełniały je odwieczne wady ludności wiejskiej: zabobonność, kłótliwość, nieroztropność. Dawne zależności wynikające z istniejącego od pokoleń ładu społecznego straciły swe zwyczajowe umocowanie, stając się kolejnymi płaszczyznami sporu wsi i dworu. Jedną z nich okazała się kwestia serwitutów. Zatargi o włościańskie uprawnienia do korzystania z dworskich gruntów niekiedy przybierały tragiczny obrót:

W lesie piotrkowskim, do hrabiego Kazimierza Starzeńskiego należącym, czterech włościan ze wsi rządowej Daniłowa zabiło leśnika dworskiego za to, że bronił im pasać bydło w cudzym lesie, do czego nie mieli serwitutowego prawa. [...] W dobrach Stelmachowo przed laty trzema podobny zamach wykonany był na nadleśnika Masłowskiego ${ }^{23}$.

23 Zygmunt G..... [Z. Gloger], Gtos ze wsi, „Niwa” 1879, [w:] tegoż, Pisma rozproszone, t. II, red. J. Leończuk i J. Ławski, Białystok 2015, s. 1040. 
Pomimo uwłaszczenia, przyznania chłopom pełni obywatelskich praw i swobód, krajobraz społeczno-gospodarczy wsi Kongresówki pozostawał daleki od ideału. Zniesienie feudalnego ładu społecznego nie przekształciło partykularza w krainę mlekiem i miodem płynącą. Parcelacja, niekiedy postrzegana jako lek na wszystkie bolączki trapiące prowincję, nie spełniła pokładanych w niej nadziei. Nie tylko nie przyniosła włościanom prawdziwej niezależności ekonomicznej, ale często pogorszyła relacje z ziemiaństwem. Zdaniem Glogera, władze carskie, burząc dotychczasowy ład, doprowadziły do chaosu:

[...] uległy rozprzedaży średnie, to jest najprodukcyjniejsze folwarki, których nie rozdzielano na kolonie, ale na zagmatwaną szachownicę zagonową, w którym niemożliwym jest prowadzenie racjonalnego, nawet najmniejszego gospodarstwa. „Zacofany” ziemianin ustępował, ale cóż działo się z majątkiem? Oto kosztowne budynki rozbierano i burzono, ogród i majestatyczne drzewa wycinano [...], ogrodzenia szły na komin, dachówkę sprzedawano dla zastąpienia tańszą słomą, na miejsce pługa powróciła przedpotopowa socha, a miejsce machin i narzędzi rolniczych zajął cep i szufla [...]. Poczta przestała dowozić czasopisma, fabryki dostarczać machin, a rzemieślnicy wyrobów. Ogniskiem życia w rozparcelowanym majątku stała się karczma [...]. Włościanie i cząstkowa szlachta, rozkupując folwarki za pieniądze w większej części u Żydów pożyczone, zabrnęła głęboko w długi lichwiarskie ${ }^{24}$.

Wydaje się, że w oczach autora Encyklopedii staropolskiej ilustrowanej prowincja po 1863 roku nie tylko nie rozwiązała trapiących ją problemów, ale uwłaszczenie przysporzyło jej nowych. Doszło do regresu obejmującego wszystkie aspekty życia codziennego. Włościanie, nieświadomi znaczenia dobrodziejstw cywilizacji, metod gospodarowania „zacofanych” ziemian, zrobili z przejętym od nich dobytkiem to, co człowiek prosty często robi z rzeczami, których nie rozumie - zlekceważyli, zniszczyli lub rozprzedali dla doraźnego zysku. Bieda, wynikająca z nieprzygotowania chłopów do gospodarowania na własny rachunek wielu z nich pchnęła do zadłużenia u żydowskich lichwiarzy, brak perspektyw na lepsze jutro skierował do karczmy. Dziecięca naiwność

24 Rolnik [Z. Gloger], Stów kilka o skutkach parcelacji, „Gazeta Warszawska” 1885, nr 285, [w:] tamże, s. 552-553. 
oraz zabobonność uczyniły ich łatwym celem wszelkiego rodzaju oszustów. Gloger wielokrotnie pisał o wiejskich spirytystach, znachorach, przytaczał historie o upiorach i wilkołakach ${ }^{25}$. Jednak przyczyn tych wszystkich bolączek nie upatrywał pod strzechą. Winą za stan prowincji obarczał ziemiaństwo, często lekceważące społeczne obowiązki, niezdolne lub niechętne kształtować nową rzeczywistość, pomóc odnaleźć się w niej dawnym poddanym ${ }^{26}$.

Konsekwencje absenteizmu z całą siłą objawiły się w czasie rewolucji 1905 roku. W relacjach Glogera wydarzenia tego okresu jawily się „niebywałych jeszcze nigdy rozmiarów w Polsce klęską: nędzy, głodu, rozbojów i braku zarobków"27, zaś terror socjalistycznych bojówek przyrównywał do czarnych dni zbiorowych egzekucji dokonywanych przez wojska Michaiła „Wieszatiela" Murawjowa ${ }^{28}$. Jednak autor Encyklopedii staropolskiej ilustrowanej winą za powszechne wówczas akty bestialstwa - rozboje, pobicia, brutalne mordy nie obarczał jedynie buntujących się warstw najniższych. W tych wstrząsających wydarzeniach upatrywał klęski „warstw oświeceńszych”, roszczących pretensje do przewodzenia narodowi. Jak bardzo zawiodły w tej roli, boleśnie unaoczniła tragedia pierwszej dekady XX wieku, gdy niewykształceni chłopi i robotnicy, pozbawieni perspektyw, marzący o lepszym jutrze, uwierzyli rojeniom socjalistycznych agitatorów ${ }^{29}$. Gloger przestrzegał przed tym zagrożeniem na długo przed rewolucją, próbował mu przeciwdziałać. W 1879 roku, promując własny cykl Biblioteczka Ludowa, pisał, że jego zadaniem jest „uczciwe zasłonienie ludu przed paczącymi się pojęciami o moralności, pra-

25 Zob. np. Z. Glogera (O owczarzu Pakielle), „Kurier Warszawski” 1877, nr 56; O wyprzedaży i rozprzedaży ziemi, „Gazeta Warszawska” 1880, nr 64, [w:] tegoż, Pisma rozproszone, t. II; Listy znad Narwi, cz. II, „Kłosy” 1890, nr 1287, [w:] tegoż, Pisma rozproszone, t. III, red. J. Leończuk i J. Ławski, Białystok 2016.

26 Zob. w II tomie Pism rozproszonych Z. Glogera Przyczynek do dziejów ogrodnictwa naszego, „Gazeta Warszawska” 1878, nr 11; Straże ochotnicze od ognia w XVI wieku, „Gazeta Warszawska” 1882, nr 178; Absenteizm, „Gazeta Rolnicza” 1878, nr 10.

27 Mazur [Z. Gloger], Przestroga, Warszawa 1906, s. 4.

28 Z. [Z. Gloger], Samobójstwo narodowe, „Gazeta Polska” 1906, nr 238, [w:] tegoż, Pisma rozproszone, t. II, s. 490-491.

29 Zagadnieniem rewolucji 1905 roku w publicystyce Glogera zajął się Jarosław Ławski. Zob. tenże, Pozytywista wobec rewolucji. Zygmunt Gloger i wydarzenia 1905 roku, [w:] O wolność i sprawiedliwość. Chrześcijańska Europa między wiara i rewolucją, red. U. Cierniak, N. Morawiec, A. Bańczyk, Częstochowa 2018. 
wie własności i legalnych stosunkach społecznych"30. Niestety, podobne inicjatywy były nieliczne. Zdaniem autora Snu ziemianina absenteizm polskich elit doprowadził do tragedii:

[...] rzemieślnicy [...] tworzą szajki bandytów, dorośli rozdają brauningi i noże fińskie dzieciom zaprawianym do mordów, nabijają starca modlącego się w czasie Rezurekcji pod kościołem łódzkim, mordują kobiety ciężarne i małe dzieci, matki i ojców licznego drobiazgu [...], tam inteligentni rzekomo młodzieńcy torturują w ohydny sposób ofiarę, nie chcąc im oddać swoich oszczędności całego życia ${ }^{31}$.

Dotychczasowe rozważania zdają się sugerować, że przemiany społeczne zachodzące po 1863 roku Gloger postrzegał skrajnie negatywnie. Ubóstwo pouwłaszczeniowej wsi, niedołęstwo umysłowe jej mieszkańców, przemoc, liczne patologie składają się na obraz społeczeństwa znajdującego się na krawędzi upadku. Jest to jednak wrażenie złudne. Gloger piętnował te zjawiska, bowiem w jego opinii należało się nad nimi pochylić ze szczególną troską. Mimo wszystko, o ludzie wiejskim zazwyczaj pisał z sympatią, dostrzegał w nim liczne zalety, które, jego zdaniem, zdecydowanie przeważały nad wadami. W oczach gospodarza $\mathrm{z}$ Jeżewa nie wynikały one $\mathrm{z}$ rozwoju tej grupy społecznej po 1863 roku, nie przyniósł ich pozytywistyczny postęp. Były właściwe ludności włościańskiej od dawna:

Dla nas, którzy się [...] co chwila ścieramy z tym usposobieniem mas ludu, jakże nielogiczne i naiwne wydają się rojenia teorii socjalistycznych, którym choćby wszystko sprzyjało, to sam lud obróci je w niwecz, bo we krwi każdego kmiecia płynie żądza powiększenia osobistego dziedzictwa, absolutnej własności, ukrytego gromadzenia kruszcu, a każdy bić się gotów lub całe życie pracować dla zdobycia piędzi ziemi na własność i umrzeć w jej obronie ${ }^{32}$.

30 [Z. Gloger], ,,Biblioteczka Ludowa”, ,Gazeta Warszawska” 1879, nr 218, [w:] tamże, s. 430.

31 Z.G. [Z. Gloger], Mord, terror i grabież w „państwie przyszłości”, „Goniec Wieczorny” 1907, [w:] tegoż, Pisma rozproszone, t. III, s. 1103.

32 Ziem. [Z. Gloger], Z Tykocińskiego, dnia 18 kwietnia, „Gazeta Handlowa” 1880, nr 88, [w:] tegoż, Pisma rozproszone, t. II, s. 1005. 
Cytat ten może wydawać się niejasny, dopóki nie rozważy się znaczenia własności ziemskiej w Glogerowskiej filozofii narodu. Według twórcy Roku polskiego była ona jednym z czynników tenże naród definiującym - obok języka i tradycji. Szacunek do niej jako dziedzictwa przodków uważał za oznakę rozwoju cywilizacyjnego - im większe przywiązanie do ziemi, tym jego poziom miał być wyższy ${ }^{33}$. Zatem w opinii Glogera polski gmin na przestrzeni wieków wykształcił w sobie przywiązanie do określonych wartości, które stało się jego immanentną cechą. Socjalistycznym agitatorom nie udało się go wykorzenić, jedynie osłabić. Autor Encyklopedii staropolskiej relacji wsi z dworem nie postrzegał jedynie przez pryzmat tarć i wzajemnych pretensji. W jego opinii były to relacje symbiotyczne, choć niekiedy reprezentujące sprzeczne interesy. Wierzył w możliwość harmonijnego współistnienia na jednym terytorium przedstawicieli różnych warstw społecznych, co jednak wymagało podjęcia długotrwałej pracy nie tylko nad edukacją oraz umoralnieniem warstw najniższych, ale również samodoskonaleniem „oświeceńszych”.

\section{Postęp czy rewolucja?}

Zarówno Manteuffel, jak Gloger, choć wywodzili się ze środowisk utożsamianych z konserwatyzmem, w stosunku do kwestii włościańskiej okazują się zaskakująco postępowi. Ich poglądy na kierunek zmian społecznych i potrzeby prowincji w wielu aspektach zbliżały się do stanowisk pozytywistów. W tym ujęciu postęp jako idea wydaje się rozmywać, zatracać wyraźną granicę ze swoją antytezą. Przytaczany Julian Ochorowicz uważał je za terminy nierozłączne, genetycznie powiązane, przy tym skazane na nieustanny konflikt. Jednak w ujęciu historiozoficznym dialektyka ta nie okazuje się czynnikiem dezintegrującym, lecz spajającym. Kolejne pokolenia, odnosząc się do spuścizny poprzedników, synchronicznie stosują dwa mechanizmy - krytykę i afirmację $e^{34}$. Pierwszy z nich, podważając stan obecny, zapobiega stagnacji, drugi

33 [Z. Gloger], W sprawie rolnej, „Kurier Warszawski” 1906, nr 203, [w:] tegoż, Pisma rozproszone, t. III, s. 343.

34 W kontekście pozytywistycznej recepcji romantyzmu o tym mechanizmie pisała Ewa Warzenica. Zob. taż, Pozytywistyczny „obóz młodych” wobec tradycji wielkiej polskiej poezji romantycznej (lata 1866-1881), Warszawa 1968, s. 12. 
stanowił jego podstawę i punkt wyjścia, który nigdy nie mógł zostać w całości zanegowany. Aleksander Świętochowski pisał: „teraźniejszość jest rezultatem przeszłości. [...] Wątku dziejów przeciąć nie można, bo któż usunie spod nóg grunt, na którym stoi?"35. Tę zależność i wynikającą z niej trudność z jednoznacznym zdefiniowaniem pojęć postępowca i konserwatysty dostrzegał również Gloger. Opisując wyimaginowaną, idealną prowincjonalną społeczność w Śnie wieśniaka, mówił:

Smutne były to czasy [...] ludzie, którzy się nazywali zachowawcami, zerwali nić tradycji, przyjęli obcą mowę, zwyczaje i tytuły, które były w pogardzie ich ojców, karczmarzom sprzedawali gniazda cnót dziadowych, a Niemcom ziemię swych przodków. Za dobrych chrześcijan uchodzili ludzie, którzy miłość bliźnich herbami mierzyli. Za postępowych uważano tylko tych, którzy zaparli się Boga i tradycji ${ }^{36}$.

W ujęciu autora Dolinami rzek terminy postępowca i konserwatysty stały się pejoratywami o zbliżonym znaczeniu - wskazywały na wyparcie, zaniechanie, choć z odmiennych pobudek. Oba wynikały z bezrefleksyjnego podążania za trendami, usunięcia podstaw, których zachowanie postulował Świętochowski. Istotą konserwatyzmu stała się tutaj pielęgnacja anachronicznego elitaryzmu bo w oczach Glogera tylko to różniło go od postępu, a właściwie abominacji postępu, której rzekomo miał się przeciwstawiać.

Manteuffel nie pozwalał sobie na tak ostrą krytykę kręgów konserwatywnych, być może ze względu na stanową solidarność, choć delikatnie punktował ich snobizm. Pod koniec lat 70. XIX wieku pisał o inflanckim ziemiaństwie, że jest ,,$[. .$.$] wolne prawie wszędzie od wszelkiej próżnej ostentacji i innych$ pseudoarystokratycznych wad i przesądów, na jakie nie bardzo dawnymi czasy $[\ldots]$ trochę chorowano"37. Dużo poważniejsze zarzuty stawiał inteligencji Inflant, którą uważał za oderwaną od rzeczywistości. Jej pragnienie zrealizo-

35 [A. Świętochowski], Tradycja i historia wobec postępu, „Przegląd Tygodniowy” 1872, nr 19, s. 147. t. II, s. 919.

36 Z. Gloger, Sen wieśniaka, „Gazeta Rolnicza” 1882, nr 1, [w:] tegoż, Pisma rozproszone,

37 G. Manteuffel, Inflanty polskie..., s. 74. 
wania ambicji zbudowania łotewskiej kultury ex nihilo uważał za fantazmat, podejmowane $\mathrm{w}$ tym celu bezrefleksyjne próby zaszczepienia zachodnich trendów literackich na grunt inflanckiego piśmiennictwa kosztem publikacji utylitarnych za szkodliwe ${ }^{38}$. Zdawał sobie sprawę, że bez odpowiedniej podbudowy, żmudnej pracy u podstaw, wszelkie wysiłki na rzecz wytworzenia kultury wysokiej były z góry skazane na porażkę. Rozumiał, że w rozwoju społecznym nie ma dróg na skróty, kolejne stopnie rozwoju cywilizacyjnego należy pokonywać sukcesywnie, w określonej kolejności. Przekonanie to podzielali Gloger, Ochorowicz, Świętochowski i wielu innych. Auguste Comte pisał, że „postęp jest rozwinięciem porządku”39 - więc może do niego dojść jedynie w środowisku uorganizowanym, już istniejącym, a więc posiadającym pewien bagaż historyczny. Nie jest on możliwy w obliczu zerwania więzi z przeszłością. Pewna doza konserwatyzmu jest niezbędna, odrzucenie doświadczeń przeszłych pokoleń mimowolnie prowadzi do regresu, oznacza konieczność przysłowiowego wymyślania koła na nowo.

Być może problem ze zdefiniowaniem pojęć postępowca i konserwatysty oraz wynikające $\mathrm{z}$ niego międzypokoleniowe konflikty są rezultatami postrzegania ich w kategoriach skrajnych, przypisywanie im antytetycznego charakteru. Tymczasem w rzeczywistości oba stany - bo chyba tak należy je postrzegać, jako tymczasowe formy ulegające przeobrażeniom wraz ze zmianami warunków, w których funkcjonują - są płynne. Z biegiem czasu pierwszy musi przeistoczyć się w drugi, zarazem nigdy nie będąc jego zupełnym przeciwieństwem. Toteż podział na postępowców i konserwatystów w stosunku do „kwestii włościańskiej” również pozostawał niewyraźny. Chyba, że mówimy o rewolucyjnym, nieuznającym kompromisów „postępie”, który jednak z prawdziwym, ewolucyjnym progresem nie ma wiele wspólnego.

38 Tenże, Lotwa ..., [w:] tegoż, Portrety ..., s. 233-236.

39 Cyt. za: A. Comte, System of positive polity, t. II, Social statics, or the abstract theory of human order, przekł. angielski z II wyd. francuskiego F. Harrison, Londyn 1875, s. 37. 


\section{Bibliografia}

Comte A., System of positive polity, t. II, Social statics, or the abstract theory of human order, przekł. angielski z II wyd. francuskiego F. Harrison, Londyn 1875.

Zygmunt G.... [Z. Gloger], Głos ze wsi, „Niwa” 1879, [w:] tegoż, Pisma rozproszone, t. II, red. J. Leończuk i J. Ławski, Białystok 2015.

[Gloger Z.], Mord, terror i grabież w „państwie przyszłości”, „Goniec Wieczorny” 1907, [w:] tegoż, Pisma rozproszone, t. III, red. J. Leończuk i J. Ławski, Białystok 2016.

[Gloger Z.], Przestroga, Warszawa 1906.

[Gloger Z.], Samobójstwo narodowe, "Gazeta Polska” 1906, nr 238, [w:] tegoż, Pisma rozproszone, t. II.

[Gloger Z.], Sen, „Dziennik Wileński” 1906, nr 4, [w:] tegoż, Pisma rozproszone, t. III.

[Gloger Z.], Sen wieśniaka, „Gazeta Rolnicza” 1882, nr 1, [w:] tegoż, Pisma rozproszone, t. II.

[Gloger Z.], Słów kilka o skutkach parcelacji, Gazeta Warszawska" 1885, nr 285, [w: ] tegoż, Pisma rozproszone, t. II.

[Gloger Z.], W sprawie rolnej, „Kurier Warszawski” 1906, nr 203, [w:] tegoż, Pisma rozproszone, t. III.

[Gloger Z.], Zgoda we wsi, „Gazeta Świąteczna” 1882, nr 86, [w:] tegoż, Pisma rozproszone, t. II.

[Gloger Z.], Z Tykocińskiego, dnia 18 kwietnia, „Gazeta Handlowa” 1880, nr 88, [w:] tegoż, Pisma rozproszone, t. II.

Komorowska T., Zygmunt Gloger. Opowieść biograficzna, Warszawa 1985.

Ławski J., Pozytywista wobec rewolucji. Zygmunt Gloger i wydarzenia 1905 roku, [w: ] O wolność i sprawiedliwość. Chrześcijańska Europa między wiarą i rewolucją, red. U. Cierniak, N. Morawiec, A. Bańczyk, Częstochowa 2018.

Ławski J., Zygmunt Gloger i wiek XIX, [w:] Z. Gloger, Pisma rozproszone, t. I, red. J. Leończuk, J. Ławski, Białystok 2014.

Manteuffel G., Inflanty, [w:] Słownik geograficzny Królestwa Polskiego i innych krajów słowiańskich, t. III, red. F. Sulimierski, B. Chlebowski, W. Walewski, Warszawa 1882.

Manteuffel G., Inflanty polskie poprzedzone ogólnym rzutem oka na siedmiowiekową przeszłość całych Inflant, [w:] tegoż, Inflanty polskie oraz listy znad Bałtyku, wstęp, red. i oprac. K. Zajas, Kraków 2009.

Manteuffel G., Listy znad Bałtyku, [w:] tegoż, Inflanty polskie oraz listy znad Bałtyku. 
Patryk Suchodolski, Postęp a konserwatyzm...

Manteuffel G., Łotwa i jej pieśni gminne, [w:] tegoż, Portrety miast inflanckich. Pieśni gminne, wstęp i red. K. Zajas, oprac. K. Łopatecki i W. Walczak, Białystok 2013.

Manteuffel G., Ulanowska Stefania: Łotysze Inflant polskich, a w szczególności z gminy Wielońskiej powiatu Rzeżyckiego, obraz etnograficzny, "Kwartalnik Historyczny" 1892, R. VI.

Ochorowicz J., Wstęp i pogląd ogólny na filozofię pozytywną, Warszawa 1872.

Syska H., Zygmunt Gloger, Warszawa 1963.

[Świętochowski A.], My i wy, „Przegląd Tygodniowy” 1871, nr 44.

[Świętochowski A.], Praca u podstaw, cz. I, „Przegląd Tygodniowy” 1873, nr 10; Cz. V, „Przegląd Tygodniowy” 1873, nr 16.

[Świętochowski A.], Tradycja i historia wobec postępu, „Przegląd Tygodniowy” 1872, $\mathrm{nr} 19$.

Ulanowska S., Łotysze Inflant polskich, a w szczególności z gminy Wielońskiej powiatu Rzeżyckiego. Obraz etnograficzny, „Zbiór Wiadomości do Antropologii Krajowej" 1891, t. XV.

Ulanowska S., [Od. p. Stefanii Ulanowskiej z Moskwy otrzymujemy następujące pismo], „Kwartalnik Historyczny” 1894, R. VIII.

Warzenica E., Pozytywistyczny „obóz młodych” wobec tradycji wielkiej polskiej poezji romantycznej (lata 1866-1881), Warszawa 1968. 